\title{
RECORDS OF DEAF MUTISM IN NORTHERN IRELAND
}

\author{
BY \\ E. A. CHEESEMAN AND A. C. STEVENSON \\ Department of Social and Preventive Medicine, The Queen's University of Belfast
}

\section{INTRODUCTION}

A recent survey of deaf mutism in Northern Ireland has produced strong evidence that about a quarter of all born deaf mutes in the population are deaf because of non-hereditary causes (Stevenson and Cheeseman, in press). Lancaster $(19.51,1954)$ has drawn attention to epidemics of deaf mutism in Australia, New Zealand, and Iceland, and has advanced presumptive, but nevertheless convincing, evidence that four out of five epidemics in Australia were the sequels to earlier epidemics of rubella. In his later study, Lancaster (1954) examined census and institutional data from several countries but did not include Northern Ireland. In the present paper we have examined the available sources of information relating to Northern Ireland to see if a high proportion of cases of congenital deafness can be explained by past epidemics.

\section{Survey Data}

The survey of deaf mutism in Northern Ireland was designed to examine the genetical aspects of hereditary deafness. To ensure the inclusion of all affected members of the population, in addition to ascertaining persons known to be "born deaf", we also ascertained all those whose deafness was alleged to have had an onset after birth but before the age of 6 years. By extending the scope of the ascertainment, it was hoped to overcome two difficulties; the first was the reluctance of subjects and their relatives to admit a congenital abnormality and the second was the imperfect history of onset (coupled with the difficulty of diagnosing deafness in infants) likely to be given by adults about their own, or their relatives disabilities at birth.

By personal examination, and reference to hospital, school, and institutional records, and to general practitioners and consultants, it was possible to exclude, with reasonable confidence, all subjects for whom there was good evidence that the deafness was associated with or consequent upon other conditions such as cerebral palsy or meningitis-that is those in whom the deafness was known to be acquired. In addition we were able to identify clinically six subjects whose congenital deafness was not in- herited. Two of these were deaf as a result of rubella during the mother's pregnancy, two after operation for Rh incompatibility, one was a cretin, and the last had congenital syphilis. For the purposes of the genetical study these were also excluded.

The details of the ascertainment and the problems of classification have been fully described elsewhere (Stevenson and Cheeseman, in press) and it is sufficient for the present purpose to note that we believe ascertainment was almost complete and that the above exclusions left a residual group of 509 subjects who were originally considered to represent adequately the hereditary deaf born in Northern Ireland.

The data from the families of these subjects undoubtedly pointed to recessive inheritance, and evidence from the deaf subjects who married and had children further suggested that there are several independent genes, possibly of different frequency in the population, which can determine deafness at birth. However, one feature of these data, and of similar data examined by Macklin (1947) and Hopkins (1947), was an unduly large number of sibships in which there was a single deaf born subject who had no other deaf born relatives and whose parents were not known to be related in any way. Undoubtedly some of the deafness in these was determined by inheritance, but we estimated that about 104 of the 424 living deaf born subjects (excluding the six cases known to be not inherited) were unlikely to be attributable to a single recessive gene. This proportion is unlikely to be materially altered by the hypothesis of several independent genes which was ultimately favoured. It is of course possible that some of the 104 were in fact acquired deaf subjects for whom misleading histories were obtained, but it seems unlikely that this source of error would account for many. Thus out of 430 living deaf born persons in the population there are probably about 110 deaf from non-hereditary causes, and in only six cases was the cause recognized, the other 104 cases could not be identified except in so far as they were members of a larger group of 202 offspring with no affected sibs born to unaffected parents. 
Birth rank and age of mother have been shown to be of aetiological importance in several congenital defects, and it would obviously be of interest to see whether or not the distributions of the 202 deaf born, which include the 104 suspected to be not inherited, conform to random expectation. Unfortunately we have no information about age of mother, but the birth rank is available with few exceptions and in Table $I$ this is given for 198 of the 202 deaf subjects. For a given sibship, size $s$, the random chance of any particular birth rank producing a deaf child is $1 / s$; if there are $n_{s}$ sibships of size $s$, the expected number of deaf born for each rank, $1,2,3 \ldots \ldots . s$, is $n_{s} / s$. If the sibship sizes range from $s=1$ to $s=t$, then for a given birth rank, $r$, the expected number of deaf born will be $\sum_{s=r}^{t}\left(n_{s} / s\right)$, and such expectations are also shown in Table I. The value of $\chi^{2}=0.37$ suggests that it is most unlikely that the distribution of the 202 single deaf cases is other than random.

An hypothesis of epidemic deafness, such as

TABLE I

BIRTH RANK OF DEAF BORN COMPARED WITH EXPECTED RANDOM DISTRIBUTION

\begin{tabular}{|c|c|c|}
\hline \multirow{2}{*}{ Birth Rank } & \multicolumn{2}{|c|}{ Deaf Born } \\
\hline & No. Observed & No. Expected \\
\hline $\begin{array}{l}1 \\
2 \\
3 \\
4 \\
5 \\
6 \\
7 \\
8+ \\
\end{array}$ & $\begin{array}{r}60 \\
46 \\
33 \\
23 \\
15 \\
10 \\
6 \\
5\end{array}$ & $\begin{array}{r}61 \cdot 71 \\
44 \cdot 71 \\
31 \cdot 71 \\
22 \cdot 71 \\
15 \cdot 71 \\
10 \cdot 91 \\
5 \cdot 24 \\
5 \cdot 32\end{array}$ \\
\hline Total $\quad . \quad \ldots$ & 198 & 198 \\
\hline
\end{tabular}

supported by Lancaster's Australian findings, might imply a seasonal distribution of births of deaf persons. The month of birth was known for 176 of the 202 single cases and a very rough test for such seasonal occurrence was made by comparison of the observed distribution by calendar months with expectation that $1 / 12$ of the total were likely to be born in each month. Observation and expectation are not materially different $\left(\chi^{2}=7 \cdot 54, D F=11\right.$, $0.80>P>0.70)$, but this can be no more than an approximate test of significance because no account can be taken of the seasonal variation of the live birth rate during the period concerned.

\section{INSTITUTIONAL DATA}

Protestant deaf children have been sent to the Ulster School for the Deaf in Northern Ireland since its foundation in 1831. Catholic deaf children have been sent for many years to two schools in Dublin, St. Joseph's and St. Margaret's, Cabra. The records of these schools were made available to us for the genetical study and were of great value in checking parents' and 'subjects' present-day statements with information recorded in the infancy of the deaf subjects. Some of the early records of the Cabra schools are no longer available, but the Ulster School records form a remarkable collection of continuous data relative to our present needs.

Each admission to the Ulster school was classified as "born deaf" or "acquired deaf" from information recorded at the time of admission and from what was known from other sources used in the recent survey. The admissions of the "born deaf" classified by year of birth are shown in Table II, excluding sixteen for whom this information was not available. This Table does not suggest that in any particular year an

TABLE II

- DISTRIBUTION OF ADMISSIONS TO ULSTER SCHOOL OF BORN DEAF BY YEAR OF BIRTH

\begin{tabular}{|c|c|c|c|c|c|c|c|c|c|c|}
\hline \multirow{2}{*}{$\begin{array}{c}\text { Decade } \\
\text { of } \\
\text { Birth }\end{array}$} & \multicolumn{10}{|c|}{ Year in Decade of Birth } \\
\hline & 0 & 1 & 2 & 3 & 4 & 5 & 6 & 7 & 8 & 9 \\
\hline $\begin{array}{l}181- \\
182- \\
183- \\
184- \\
185- \\
186- \\
187- \\
188- \\
189- \\
190- \\
191- \\
192- \\
193- \\
194-\end{array}$ & $\begin{array}{l}\overline{7} \\
10 \\
6(1) \\
17 \\
8 \\
11(3) \\
9(1) \\
12(2) \\
8(2) \\
6 \\
8 \\
2 \\
6\end{array}$ & $\begin{array}{l}7 \\
6 \\
6 \\
6 \\
13 \\
9(2) \\
9(1) \\
6(1) \\
7(1) \\
6(1) \\
1 \\
7 \\
8\end{array}$ & $\begin{array}{c}7 \\
77 \\
7 \\
12 \\
9 \\
9(1) \\
9(4) \\
10(2) \\
11(1) \\
2(1) \\
3(1) \\
3 \\
6\end{array}$ & $\begin{array}{l}- \\
\overline{15} \\
9 \\
14 \\
17(1) \\
13(2) \\
5(1) \\
9(2) \\
8(1) \\
6(1) \\
6(1) \\
25 \\
5\end{array}$ & $\begin{array}{c}7 \overline{7} \\
11 \\
15(1) \\
10 \\
9(1) \\
9(1) \\
11(2) \\
6 \\
4 \\
4 \\
4(2) \\
7 \\
5\end{array}$ & $\begin{array}{c}73 \\
14 \\
5 \\
9 \\
8 \\
8(3) \\
10(2) \\
5 \\
9(1) \\
7(2) \\
2 \\
8 \\
12(1)\end{array}$ & $\begin{array}{l}72 \\
17 \\
9 \\
17(1) \\
13(3) \\
8(2) \\
6 \\
11(1) \\
10(1) \\
12(2) \\
3 \\
5 \\
8\end{array}$ & $\begin{array}{l}76 \\
11 \\
15 \\
17(1) \\
6 \\
8(1) \\
5 \\
10(1) \\
8 \\
8 \\
6 \\
5 \\
3\end{array}$ & $\begin{array}{l}1 \\
4 \\
10(1) \\
11 \\
11(2) \\
7(1) \\
8(2) \\
9(1) \\
6(1) \\
5 \\
4(2) \\
2 \\
8(1) \\
1\end{array}$ & $\begin{array}{l}1 \\
6 \\
6 \\
12 \\
10(1) \\
12(1) \\
16(3) \\
13(3) \\
9(1) \\
6 \\
3(1) \\
6 \\
8 \\
3\end{array}$ \\
\hline
\end{tabular}
Figures in brackets show number "born deaf" of consanguieneous parents; they are included in preceding figures. Consanguinity was recorded
on admission sheets after 1857 .

This Table does not include sixteen "born deaf" for whom the year of birth is unknown. 
unusually large number of deaf children were born and who were subsequently admitted to the Ulster School; but the interpretation of this Table is difficult for several reasons. No allowance can be made for fluctuations in the birth rate, the relevant rate being restricted to the Protestant population. Again, the number of vacancies for new pupils was always limited and never necessarily large enough to absorb all applicants for admission. Finally, a small proportion of children were admitted from outside Northern Ireland.

Each year of birth was examined for evidence of a concentration of births of deaf infants in a particular season of the year. Unfortunately month of birth was not recorded in 92 cases although two-thirds of these omissions referred to births before 1840 . Never more than five births were recorded in any one month. In fact, this figure was reached only twice, the first occasion being May, 1902, and the second December, 1916. The numbers of such births in months immediately before and after these maxima are of interest. In April and June, 1902, there were no recorded cases, and in November, 1916, and January, 1917, there was one case in each month. Only on six occasions were four deaf mute births recorded: March, 1846; May, 1847; January, 1852; April, 1880; April, 1920; September, 1938.

There were no deaf mute births in the months immediately before and after March, 1846, January, 1852, and September, 1938. There was one deaf infant born in April and one in June, 1847, one in March but none in May, 1880, and none in March and two in April, 1920.

It seems unlikely that these data alone can offer any evidence of deafness epidemics, but because of their limited representation of the community as a whole they do not rule out the possibility that such epidemics occurred.

\section{Census Data}

In his earlier work Lancaster (1951) reported the census enumerations of deaf mutes in New South Wales in 1911, 1921, and 1933. Here there was well defined evidence of maximum prevalence occurring at ages 10-14, 20-24, and 30-34 years of age respectively. This indicated an unusually high number of births of deaf mutes in the last few years of the 19th century, later described as the epidemic of 1899. The observations of Wickens (1927) and Wilson (Australia, 1941) led to a detailed study (Lancaster, 1954) of institutional data, from which it was concluded that there were subsequent outbreaks in 1916, 1924-5, and 1938-41. Except in 1916 , these outbreaks were preceded by epidemics of rubella.
From 1851-1911 the enumeration of the deaf and dumb in the Irish censuses was supplemented by special inquiries about each person enumerated. The detailed procedure, which did not materially alter during the 60 years, has been described by the Census Commissioners for Ireland (1854) and discussed at length by Wilde (1853, a, b). Potentially the available data were of considerable value for genetical examination. Successive reports emphasized that their value depended upon the completeness of the original enumeration and upon the efficiency of the subsequent classification of the deafness encountered. For reasons which will emerge, it is unlikely that the ascertainment was ever complete or the classification ever perfect. Nevertheless it is clear, particularly from Wilde (1853a), that the supplementary inquiries were conscientiously undertaken, even to the extent of obtaining local medical opinion in cases of clinical doubt. Unfortunately the original records are no longer available (RegistrarGeneral for Northern Ireland, 1954) and thus examination of the data must be restricted to that published in the census reports. In the latter the deaf individual, rather than his or her sibship, was usually the unit of reference so that further analysis is largely limited to examination of the prevalence of deaf mutism in population groups.

In the Irish census reports, the deaf and dumb were classified as "congenital", "acquired", or "uncertain or unknown". In what follows, these have been described as "born deaf", "acquired deaf", and "doubtful" to bring the terminology into line with that of the main survey. The classification and the difficulties presented in classifying particular individuals are dealt with in detail by the Census Commissioners for Ireland (1854) and by Stevenson and Cheeseman (in press). The doubtful group in the census reports, which never exceeded 7 per cent. of all deaf and dumb, was composed largely of persons who were enumerated on routine census schedules but for whom answers to supplementary inquiry could not be obtained.

Table III (opposite) sets out the prevalence rates at each census according to the type of deafness recorded.

It is clear that in 60 years there has been very little change in total prevalence. However, the rates suggest a change in the ratio of "born deaf" to "acquired deaf" which may be real or which may reflect more efficient diagnosis. Consistently there was relatively more deafness enumerated among men than among women.

The information collected which is of specific interest in the present context is the age, sex, place of residence, and classification of type of deafness. 
TABLE III

PREVALENCE OF DEAF AND DUMB PERSONS IN IRELAND BY CLASSIFICATION OF CONDITION, 1851-1911 (Number of affected persons per 100,000 of population)

\begin{tabular}{|c|c|c|c|c|c|c|c|c|c|c|c|}
\hline \multirow{2}{*}{ Sex } & \multirow{2}{*}{\multicolumn{4}{|c|}{ Classification }} & \multicolumn{7}{|c|}{ Census Year } \\
\hline & & & & & 1851 & 1861 & 1871 & 1881 & 1891 & 1901 & 1911 \\
\hline \multirow[t]{2}{*}{ Male } & $\begin{array}{l}\text { "Born Deaf" } \\
\text { "Acquired Deaf" . } \\
\text { "Doubtful" } \\
\text {.. }\end{array}$ & $\begin{array}{l}\cdots \\
\cdots\end{array}$ & $\begin{array}{l}\cdots \\
\cdots\end{array}$ & $\begin{array}{l}\cdots \\
\cdots\end{array}$ & $\begin{array}{r}70 \\
9 \\
6\end{array}$ & $\begin{array}{r}80 \\
11 \\
3\end{array}$ & $\begin{array}{c}73 \\
18 \\
2 \\
\end{array}$ & $\begin{array}{r}68 \\
16 \\
1\end{array}$ & $\begin{array}{r}59 \\
17 \\
1\end{array}$ & $\begin{array}{r}54 \\
18 \\
4\end{array}$ & $\begin{array}{r}58 \\
19 \\
2\end{array}$ \\
\hline & Total & $\ldots$ & . & . & 84 & 95 & 93 & 85 & 78 & 75 & 80 \\
\hline \multirow[t]{2}{*}{ Female } & $\begin{array}{l}\text { "Born Deaf" } \\
\text { "Acquired Deaf" . } \\
\text { "Doubtful" }\end{array}$ & $\begin{array}{l}\cdots \\
\cdots\end{array}$ & $\begin{array}{l}\cdots \\
\cdots\end{array}$ & $\begin{array}{l}\ddot{ } \\
\ddot{*}\end{array}$ & $\begin{array}{r}49 \\
8 \\
-\quad 4\end{array}$ & $\begin{array}{r}62 \\
11 \\
3\end{array}$ & $\begin{array}{r}57 \\
14 \\
2\end{array}$ & $\begin{array}{r}54 \\
14 \\
1\end{array}$ & $\begin{array}{r}50 \\
15 \\
1\end{array}$ & $\begin{array}{r}44 \\
16 \\
3\end{array}$ & $\begin{array}{r}48 \\
14 \\
2\end{array}$ \\
\hline & Total $\quad \ldots$ & $\cdots$ & $\cdots$ & . & 61 & 76 & 72 & 69 & 65 & 63 & 63 \\
\hline \multirow[t]{2}{*}{ Total } & $\begin{array}{l}\text { "Born Deaf"” } \\
\text { "Acquired Deaf", .. } \\
\text { "Doubtful" }\end{array}$ & $\begin{array}{l}\cdots \\
\cdots\end{array}$ & $\begin{array}{l}\cdots \\
\cdots\end{array}$ & $\begin{array}{l}\cdots \\
\cdots\end{array}$ & $\begin{array}{r}59 \\
8 \\
5\end{array}$ & $\begin{array}{r}71 \\
11 \\
3\end{array}$ & $\begin{array}{r}65 \\
16 \\
2\end{array}$ & $\begin{array}{r}61 \\
15 \\
1\end{array}$ & $\begin{array}{r}55 \\
16 \\
1\end{array}$ & $\begin{array}{r}49 \\
17 \\
3\end{array}$ & $\begin{array}{r}53 \\
17 \\
2\end{array}$ \\
\hline & Total & $\ldots$ & $\cdots$ & . & 72 & 85 & 83 & 77 & 72 & 69 & 72 \\
\hline
\end{tabular}

Unfortunately the age and sex distributions are available for the deaf born, only for the whole of Ireland and only for the years 1881,1901 , and 1911 . Moreover in these distributions the doubtful cases are included with the "born deaf". Table IV shows that where the classification by age can be made for the "born deaf" (including doubtful), the higher prevalence among men is a feature of most age groups, and that there was, with few exceptions, a lower prevalence rate in 1901 and 1911 than in 1881 . As in Table III, the secular trend may be a result of improved diagnosis but this seems unlikely to be an explanation of the sex difference.

\section{TABLE IV}

PREVALENCE OF "BORN DEAF" AND "DOUBTFUL" IN IRELAND CLASSIFIED BY AGE AND SEX,

$$
\text { 1 1881, 1901, AND } 1911
$$

(Number of affected persons per 100,000 of population)

\begin{tabular}{|c|c|c|c|c|c|c|c|c|c|}
\hline \multirow{3}{*}{$\begin{array}{c}\text { Age Group } \\
\text { (yrs) }\end{array}$} & \multicolumn{9}{|c|}{ Sex } \\
\hline & \multicolumn{3}{|c|}{ Male } & \multicolumn{3}{|c|}{ Female } & \multicolumn{3}{|c|}{ Total } \\
\hline & 1881 & 1901 & 1911 & 1881 & 1901 & 1911 & 1881 & 1901 & 1911 \\
\hline $\begin{array}{r}0-4 \\
5-9 \\
10-14 \\
15-19 \\
20-24 \\
25-29 \\
30-39 \\
40-49 \\
50-59 \\
60-69 \\
70+ \\
\end{array}$ & $\begin{array}{r}5 \\
48 \\
64 \\
69 \\
79 \\
89 \\
99 \\
91 \\
105 \\
95 \\
59 \\
\end{array}$ & $\begin{array}{r}5 \\
28 \\
48 \\
67 \\
57 \\
70 \\
72 \\
75 \\
92 \\
73 \\
65\end{array}$ & $\begin{array}{r}5 \\
36 \\
57 \\
52 \\
62 \\
77 \\
79 \\
73 \\
80 \\
95 \\
75\end{array}$ & $\begin{array}{r}7 \\
37 \\
45 \\
52 \\
54 \\
76 \\
80 \\
82 \\
84 \\
60 \\
54\end{array}$ & $\begin{array}{r}2 \\
29 \\
41 \\
55 \\
41 \\
51 \\
55 \\
65 \\
60 \\
58 \\
72\end{array}$ & $\begin{array}{r}4 \\
28 \\
51 \\
49 \\
50 \\
53 \\
57 \\
61 \\
74 \\
72 \\
55\end{array}$ & $\begin{array}{l}6 \\
43 \\
55 \\
60 \\
66 \\
82 \\
89 \\
86 \\
94 \\
77 \\
56\end{array}$ & $\begin{array}{r}3 \\
29 \\
45 \\
61 \\
49 \\
60 \\
63 \\
70 \\
75 \\
66 \\
69\end{array}$ & $\begin{array}{l}35 \\
32 \\
54 \\
51 \\
56 \\
65 \\
68 \\
67 \\
77 \\
83 \\
64\end{array}$ \\
\hline Total & 69 & 58 & 61 & 56 & 47 & 49 & 62 & 52 & 55 \\
\hline
\end{tabular}

In all three years 1881, 1901, and 1911 the prevalence among the very young was never more than 7 per 100,000 , this is undoubtedly due to a low stan- dard of ascertainment and failure to recognize deafness in infants. After the age of 5 years the prevalence rises fairly steadily to a maximum at ages 50-59 in 1881 and 1901, and 60-69 in 1911.

Other influences being constant, evidence of epidemic deafness would be revealed by high prevalence rates in the same generation at each census. Thus an unusually high rate in a given age group in 1881 would be followed by similary high rates in age groups 20 years older in 1901 and 30 years older in 1911. In the Table the nearest approach to such a series is seen in the rates of 89 , 75 , and 83 per 100,000 at ages $30-39,50-59$, and 60-69 in 1881, 1901, and 1911 respectively. In these the last two were the maxima of the age-specific rates in the census years concerned; in 1881 the rate of 89 per 100,000 is an irregularity in the gradual increase in the rates with age. Although this observation might be suggestive, the size of the rates is clearly not indicative of any heavy epidemic, and as in the last two censuses it represents the natural maxima of the age-prevalence curve, interpretation depends mainly on the observation of the high level in 1881 occurring at an age which disturbs the general upward trend of the rates with increasing age. If this high rate was due to an earlier epidemic of deafness at birth, then the epidemic must have occurred in the decade 1842-1851, and the school data would be suggestive of 1846 or 1847 . Numerically, however, such an epidemic, even if real, was unimportant, and it occurred too early to have an effect on the current survey of deafness in Northern Ireland.

- Certainly there is nothing in Table III comparable with the epidemic evidence of the census data of New South Wales. Here the actual number of male 
deaf mutes enumerated [Lancaster (1991) does not quote the rates] was 54 at 10-14 years of age in 1911 compared with 34 and 35 in the adjoining 5-year age groups, 69 at 20-24 in 1921 compared with 30 and 36 , and 78 at 30-34 in 1933 compared with 44 and 44. For females the numbers were 57 in 1911 compared with 25 and 29, 46 in 1921 compared with 27 and 23, and 62 in 1933 compared with 25 and 27.

\section{SUMmARY AND CONCLUSIONS}

An examination of the Irish census enumerations from 1851 to 1911 with particular reference to the age distributions available for 1881,1901 , and 1911, gives no indication of any generation of people in whom a particularly high proportion were "born deaf".

Similarly, admission records of a school for the deaf fail to reveal evidence of an unduly large number of children having been "born deaf" in any particular year or calendar month.

These findings are of interest as presumptive evidence exists that in about one-quarter of the deaf born persons at present living in Northern Ireland the deafness was not of genetical origin.

The hypothesis that some of this non-genetically determined deafness is attributable to maternal infections in early pregnancy is thus not supported by the census and school data. However, they cannot exclude such an hypothesis because of their inherent limitations.

Because the deafness of genetical and nongenetical origin cannot be efficiently distinguished, direct examination of the latter is not possible in the majority of cases. However the distributions by rank and season of birth of a group of living deaf born persons with unaffected sibs and parents, of whom probably one-half are deaf from non-genetical causes, could easily have occurred by chance $(P>0 \cdot 7)$.

We are indebted to Mr. J. D. Merrett, Mr. Scott Crockett, and Miss D. B. I. Wood, of the Department of Social and Preventive Medicine, The Queen's University of Belfast, for their help in the preparation of this paper.

\section{REFERENCES}

Australia, Commonwealth Bureau of Census and Statistics (1941). "Census of the Commonwealth of Australia, 1933" (R. Wilson, Commonwealth Statistician), vol, 2, p. 1005 . Government Printer, Melbourne.

Hopkins, L. A. (1947). Trans. Amer. otol. Soc., 34, 164.

Ireland, Census Commissioners (1854). "Census of Ireland, 1851". H.M.S.O., Dublin.

Lancaster, H. O. (1951). Brit. med. J., 2, 1429.

(1954). Acta genet. (Basel), 5, 12.

Macklin, M. T. (1947). Trans. Amer. otol. Soc., 34, 177.

Registrar-General for Northern Ireland (1954). Personal communication.

Stevenson, A. C., and Cheeseman, E. A. (in press). Ann. hum. Genet. (Lond.).

Wickens, C. H. (1927). "Census of the Commonwealth of Austrlia, 1921". Government Printer, Melbourne.

Wilde, W. R. (1853a). "Practical Observations on Aural Surgery". Churchill, London.

- (1853b). J. statist. Soc. Lond., 16, 69. 